\title{
PENGARUH PERPADUAN MODEL THINK PAIR SHARE (TPS) DAN POLA PEMBERDAYAAN BERPIKIR MELALUI PERTANYAAN (PBMP) TERHADAP KEMAMPUAN BERPIKIR KRITIS SISWA DI SMA NEGERI 10 KOTA TERNATE
}

\author{
Asri Idhar', Ade Haerullah', ${ }^{2}$, Chumidach Roini ${ }^{3}$ \\ ${ }^{1)}$ Guru Biologi - SMA Negeri 10 Kota Ternate \\ 2), 3) Magister Pendidikan Biologi Universitas Khairun \\ Email: Asri_idhar@yahoo.go.id
}

\begin{abstract}
Abstrak
Proses pembelajaran menitikberatkan pada nilai dan pencapaian materi dalam kurikulum. Akibatnya, pembelajaran yang dilakukan cenderung bersifat informatif, teacher-centered, dan kurang memberdayakan proses berpikir siswa. Permasalahan tersebut dapat diatasi dengan dengan menerapkan perpaduan model TPS + PBMP. Penelitian ini dilakukan untuk mengetahui pengaruh perpaduan model pembelajaran Think Pair Share dan Pola Pemberdayaan Berpikir Melalui Pertanyaan terhadap kemampuan berpikir kritis. Desain penelitian adalah penelitian quasi eksperimen dengan menggunakan Pre-test-Post-test Nonequivalent Control Group Design atau Nonrandomized Control Group Pre-test-Posttest Design. Sampel penelitian adalah siswa kelas XI IPA-1 sebagai kelas eksperimen dan kelas IPA-2 dan IPA-3 sebagai kelas kontrol. Pengukuran kemampuan berpikir kritis menggunakan rubrik kemampuan berpikir kritis yang yang mengacu kepada Hart. Hasil analisis anakova menunjukkan bahwa pembelajaran berpola PBMP dipadu TPS lebih berpotensi meningkatkan kemampuan berpikir kritis siswa dan tidak terlalu berbeda nyata dengan model TPS dan PBMP.
\end{abstract}

Kata kunci: Think Pair Share, Pemberdayaan Berpikir Melalui Pertanyan, kemampuan berpikir kritis,

\section{PENDAHULUAN}

Pembelajaran merupakan usaha sistematis yang terorganisasi untuk memajukan proses belajar, membina kondisi dan menyediakan kegiatan-kegiatan yang mengakibatkan peristiwa belajar. Pembelajaran yang menekankan fungsi dari pembelajaran adalah suatu perubahan yang dapat memberikan hasil jika peserta didik berinteraksi dengan informasi yang berupa materi, kegiatan dan pengalaman. Biologi sebagai bagian dari pendidikan Sains menekankan pada pemberian pengalaman langsung untuk mengembangkan kompetensi agar peserta didik mampu memahami alam sekitar secara ilmiah. Dalam mewujudkan keterampilan berpikir serta keterampilan mengembangkan sikap untuk menjalankan metode penyelidikan ilmiah dibutuhkan suatu pendekatan pengajaran yang melibatkan peserta didik secara aktif dalam kegiatan pembelajaran. 
Salah satu model pembelajaran yang berpotensi memberdayakan kemampuan berpikir kritis adalah pola pemberdayaan berpikir melalui pertanyaan. Pola PBMP sesuai dengan teori kontruktivisme yang digagas Piaget dan Vigotsky. Ibrahim dalam Meha (2006) menyebutkan esensi teori kontruktivisme adalah peserta didik harus secara individu menemukan dan menginformasikan informasi kompleks apabila mereka menginginkan informasi itu menjadi miliknya. Teori ini menganjurkan peran yang lebih aktif bagi peserta didik. Strategi kontruktivisme sering disebut pengajaran yang berpusat pada peserta didik (student centered intruction) karena penekanannya pada peran aktif peserta didik. Guru berperan membantu peserta didik menemukan fakta, konsep atau prinsip bagi peserta didik, bukan memberikan ceramah atau mengendalikan seluruh kegiatan kelas.

Pembelajaran pola PBMP bukan pembelajaran yang bersifat informatif tetapi pembelajaran yang lebih mengutamakan pertanyaan-pertanyaan yang tersusun sistematis dan terorganisasi secara utuh dalam lembar PBMP. Peserta didik akan berusaha untuk menjawab pertanyaan-pertanyaan yang ada di dalam lembar PBMP yang berupa suatu masalah sehingga memicu peserta didik untuk berpikir dan menemukan jawaban dari pertanyaan yang ada. Dengan demikian peserta didik akan memecahkan suatu masalah dengan cara berpikirnya sehingga kemampuan berpikir kritis berkembang. Lembar Kerja siswa (LS) pola PBMP harus disusun sedemikian rupa sehingga aktivitas peerta didik untuk menemukan jawaban yang ada pada pertanyaan pada LS dapat melakukan suatu proses kognitif yaitu pengelolaan diri dan evaluasi diri.

Model pembelajaran Think Pair Share merupakan salah satu metode dalam pembelajaran kooperatif yang dikembangkan oleh Franky Lyman dan kawankawannya yang tergolong dalam pembelajaran kontruktivisme. Menurut Haerullah (2013) bahwa pembelajaran kooperatif dapat menciptakan suasana kebersamaan dan saling menghargai antara siswa. Pembelajaran kooperatif dapat dioptimalkan dalam rangka meredam sensivitas dan egoisme siswa secara dini di sekolahsekolah. Strategi pembelajaran TPS merupakan salah satu pembelajaran kooperatif yang menekankan adanya proses berpikir (thinking), berkelompok dan berpasangan (pairing) dan berbagi (sharing). Hasil penelitian sebelumnya menunjukkan bahwa pembelajaran TPS maupun perpaduan TPS dengan strategi lain membantu siswa dalam meningkatkan hasil belajar kognitif,berpikir kritis,berpikir kreatif, minat dan kerja sama anggota dalam kelompok.

Menurut Haerullah (2013) bahwa pembelajaran koperatif dapat menciptakan susana kebersamaan dan saling menghargai antara siswa. Pembelajaran kooperatif dapat memperdayakan kemampuan berpikir kritis, hasil belajar kognitif karena di 
dalam pembelajaran kooperatif terjadi proses pembelajaran yang memungkinkan peserta didik dalam kelompoknya mengevaluasi kerja tiap kelompok, memperbaiki interaksi sosial, juga adanya upaya memperbaiki penampilan tiap anggota kelompok (Green, dalam Corebima, 2008). Pembelajaran kooperatif dapat memperdayakan kemampuan berpikir kritis, karena memberikan kesempatan kepada peserta didik untuk berdiskusi dengan anggota kelompoknya dalam memecahkan masalah yang dihadapi sehingga muncul alternatif jawaban dari masing-masing anggota pada akhirnya akan menemukan jawaban terbaik pada tiap kelompok.

Keunggulan pola pemberdayaan berpikir melalui pertanyaan dengan model pembelajaran Think Pair Share adalah sama-sama dapat memperdayakan kemampuan berpikir kritis mahasiswa, model pembelajaran ini memberikan kesempatan mahasiswa untuk dapat memecahkan masalah sendiri, kemudian sharing kepada teman dan berdiskusi dengan teman satu kelas dan melatih mahasiswa untuk mengungkapkan pendapatnya dan berdiskusi yang bertujuan memperoleh suatu konsep pembelajaran yang diharapkan.

Beberapa penelitian telah membuktikan manfaat dari pembelajaran pola pemberdayaan berpikir melalui pertanyaan dan model pembelajaran Think Pair Share. Hasil penelitian Hartati (2010), model pembelajaran Think Pair Share yang dipadu dengan pola pemberdayaan berpikir melalui pertanyaan dapat meningkatkan keterampilan metakognitif, kemampuan berpikir kritis dan hasil belajar kognitif. Hasil penelitian Suyanik (2010), membuktikan bahwa pemberdayaan berpikir melalui pertanyaan dengan model pembelajaran Think Pair Share berpengaruh secara signifikan terhadap hasil belajar kognitif. Hasil penelitian Haerullah (2012), pola Pemberdayaan Berpikir Melalui Pertanyaan dan Thing Pair Share dapat meningkatkan metakognisi,berpikir kritis dan sikap sosial siswa.

Berdasarkan uraian di atas maka diperlukan metode pembelajaran yang tepat dalam menyajikan materi Struktur dan Fungsi Sel Penyusun Jaringan Tumbuhan yaitu Perpaduan model pembelajaran Think Pair Share dan pola Pemberdayaan Berpikir Melalui Pertanyaan diharapkan agar guru lebih menekan pada pengembangan kemampuan peserta didik agar mudah memahami, termotivasi dan lebih aktif sehingga kemampuan berpikir kritis dapat meningkat.

Kondisi pembelajaran di SMA Negeri 10 Kota Ternate masih tergolong pembelajaran yang konvensional. Hasil pengamatan terhadap peserta didik SMA Negeri 10 Kota Ternate, terkait dengan keterampilan berpikir kritis, terungkap bahwa masih banyak peserta didik yang kurang memiliki kemampuan untuk 
berargumentasi. Peserta didik kurang memiliki kemampuan mengemukakan pendapat, memberikan alternatif pemecaham masalah dalam kegiatan diskusi di kelas. Peserta didik lebih cenderung pasif (diam), baik saat diskusi, maupun bentuk kegiatan belajar lain. Selain itu, peserta didik masih belum mampu membuat kesimpulan terhadap permasalahan yang di diskusikan. Suasana pembelajaran yang cenderung konvensional pun masih mendominasi pembelajaran, terutama dalam mata pelajaran biologi. Hal ini terjadi juga dengan hasil belajar kognitif pada mata pelajaran biologi terutama pada materi Struktur dan Fungsi Sel Penyusun Jaringan Tumbuhan yang diperoleh peserta didik angkatan sebelumnya masih jauh dari harapan, terungkap bahwa peserta didik yang mencapai ketuntasan belajarnya hanya mencapai $47 \%$ saja. Jika diamati perkembangan hasil belajar kognitif biologi maka terjadi fluktuasi nilai.

Hasil observasi terhadap 10 rekan guru SMA Negeri 10 Kota Ternete menunjukkan bahwa penerapan model koperatif sangat rendah,selain itu para guru juga belum sepenuhnya berupaya untuk memberdayakan berpikir kritis siswa, ini telah terbukti pada rendahnya kemampuan akademik siswa yang tergambar dari hasil belajar sebagaimana telah dijelaskan paragraf sebelumnya.

Berdasarkan uraian di atas maka diperlukan metode pembelajaran yang tepat dalam menyajikan materi Struktur dan Fungsi Sel Penyusun Jaringan Tumbuhan yaitu Perpaduan model pembelajaran Think Pair Share dan pola Pemberdayaan Berpikir Melalui Pertanyaan diharapkan agar guru lebih menekan pada pengembangan kemampuan peserta didik agar mudah memahami, termotivasi dan lebih aktif sehingga kemampuan berpikir kritis dapat meningkat.

Berdasarkan peran dan fungsinya tersebut maka diinginkan keberhasilan seorang siswa dalam menyelesaikan studi tidak terlepas dari keberhasilan dalam belajar biologi. Melihat kenyataan yang terjadi di SMA Negeri 10 Kota Ternate terdapat kelemahan ditinjau dari model pembelajaran dalam meningkatkan kemampuan berpikir kritis peserta didik. Pentingnya dilakukan penelitian ini diharapan agar peserta didik memiliki kemampuan berpikir kritis yang tinggi. Berdasarkan latar belakang yang telah diuraikan diatas , maka dilakukan penelitian dengan judul" Pengaruh perpaduan Model Pembelajaran Think Pair Share dan Pola Pemberdayaan Berpikir Melalui Pertanyaan terhadap kemampuan berpikir kritis siswa di SMA Negeri 10 Kota Ternate". 


\section{METODE PENELITIAN}

Jenis penelitian ini adalah quasi experimen desain penelitiannya pretespostes Nonequivalent Control Group Design. Subyek dalam penelitian ini adalah keseluruhan peserta didik kelas XI IPA tahun pelajaran 2018/2019 yang terdiri dari 3 kelas dengan jumlah total 108 peserta didik. Sampel dalam penelitian ini adalah kelas XI IPA-1 sebagai kelas eksperimen dan kelas XI IPA-2 dan IPA-3 sebagai kelas kontrol. Pemilihan kelas tersebut dilakukan secara acak. Untuk mengetahui kemampuan awal peserta didik dilakukan dengan pelaksanaan pretest. Hasil akhirnya di lihat dengan melaksanakan posttest.

Instrumen yang digunakan dalam penelitian ini terdiri atas lembar observasi pembelajaran, perangkat pembelajaran yang dimaksud meliputi silabus, buku ajar peserta didik, dan RPP, rubrik lembar kerja siswa yang berkarakter TPS + PBMP dan Tes. Bentuk tes adalah soal uraian untuk mengukur kemampuan berpikir kritis.

Proses pengumpulan data yang dilakukan dalam penelitian ini meliputi; (a) melakukan pretes pada kelas perlakuan maupun kelas kontrol (pretes dilakukan satu kali selama penelitian. (b) melaksanakan proses pembelajaran dengan menerapkan perpaduan model pembelajaran Think Pair Share dan PBMP pada kelas perlakuan, sedangkan untuk kelas kontrol adalah model TPS. (c) melakukan posttes setelah waktu penelitian berakhir, postes dilakukan satu kali selama penelitian. Kemampuan berpikir kritis diukur dengan menggunakan rubrik penskoran kemampuan berpikir kritis.

\section{HASIL PENELITIAN DAN PEMBAHASAN}

\section{Hasil Penelitian}

\section{Deskripsi Data}

Variabel bebas yang digunakan dalam penelitian ini yaitu model perpaduan PBMP + TPS dan Think Pair Share (TPS). Sedangkan variabel terikat dalam penelitian ini meliputi kemampuan berpikir kritis sisiwa. Perolehan skor kemampuan berpikir kritis mempunyai angka skor 0-100, yang mana dilakukan perhitungannya sebagai berikut skor perolehan siswa dibagi dengan skor maksimal dikalikan dengan $100 \%$.

\section{Deskripsi Data Kemampuan Berpikir Kritis} 4.1.

Profil kemampuan berpikir kritis dapat dilihat pada Gambar diagram batang 


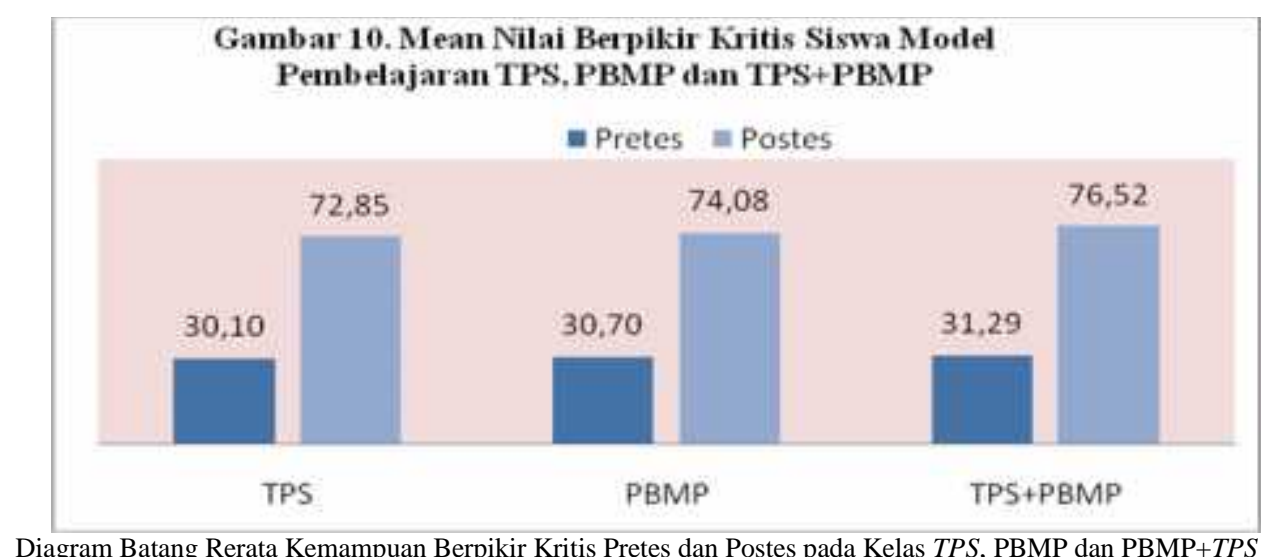

Deskripsi data kemampuan berpikir kritis materi struktur dan fungsi sel jaringan tumbuhan berdasarkan gambar di atas dapat dilihat perubahan nilai kemampuan berpikir kritis kelas TPS pretest sebesar 30,10 dan postest sebesar 72,85 nilai kemampuan berpikir kritis pada model pembelajaran PBMP pretest sebesar 30,70 dan postest 74,08 dan PBMP+TPS pretes sebesar 31,29 dan postes sebesar 76,52.

\section{Hasil Pengujian Hipotesis Data Kemampuan Berpikir Kritis}

Berdasarkan data Tabel 1 menunjukan bahwa nilai probabilitas model pembelajaran 0.000 atau kurang dari 0,005 sehingga hipotesis nol ditolak dan hipotesis penelitian diterima. Artinya model pembelajaran berpengaruh terhadap kemampuan berpikir kritis siswa.

Uji lanjut analisis $\mathrm{T}$ (Least Significant Difference) dilakukan untuk mengetahui macam model pembelajaran yang memberikan pengaruh paling tinggi dalam meningkatkan kemampuan berpikir kritis siswa.

Tabel 1. Ringkasan Hasil Uji Anakova Pengaruh Perlakuan terhadap Kemampuan Berpikir Kritis

\begin{tabular}{|l|r|r|r|r|r|}
\hline Source & Type III Sum of Squares & df & Mean Square & \multicolumn{1}{|c|}{ F } & \multicolumn{1}{|c|}{ Sig. } \\
\hline Corrected Model & $235.543^{\mathrm{a}}$ & 3 & 78.514 & 14.816 & .000 \\
Intercept & 8426.454 & 1 & 8426.454 & $1.590 \mathrm{E} 3$ & .000 \\
Pretes & 8.985 & 1 & 8.985 & 1.696 & .196 \\
Model_Belajar & 212.893 & 2 & 106.447 & 20.087 & .000 \\
Error & 498.125 & 94 & 5.299 & & \\
Total & 544112.965 & 98 & & & \\
Corrected Total & 733.668 & 97 & & & \\
\hline
\end{tabular}


Pada tabel 2, menunjukan hasil uji lanjut pengaruh model pembelajaran terhadap kemampuan berpikir kritis siswa pada kelas ekpserimen dan kontrol.

Tabel 2. Perbandingan Retata Terkoreksi Pengaruh Model Pembelajaran terhadap Kemampuan

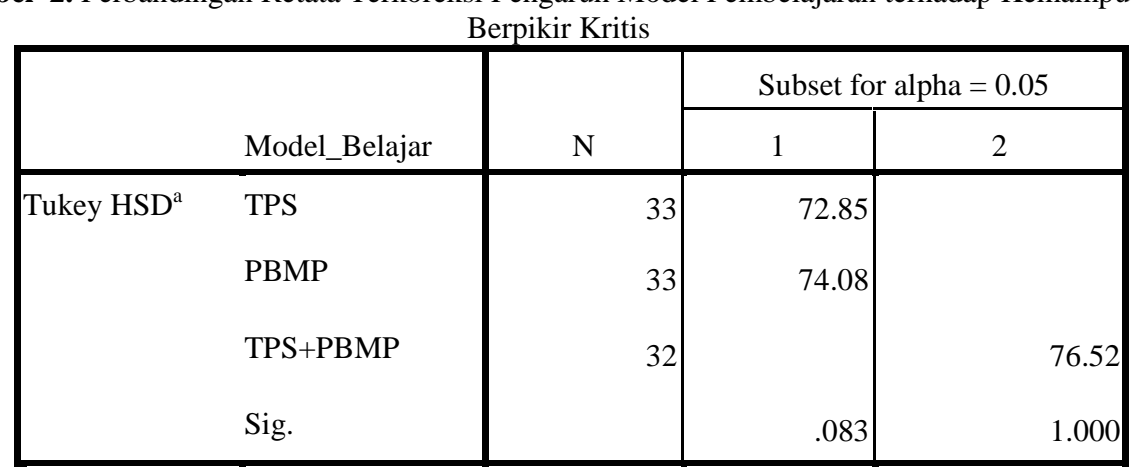

Hasil uji lanjut dengan menggunakan notasi LSD menunjukan bahwa model pembelajaran PBMP+TPS dapat meningkatkan kemampuan berpikir kritis paling tinggi dan berbeda nyata dengan model pembelajaran TPS dan PBMP. Kemampuan berpikir kritis siswa yang diajarkan dengan model pembelajaran PBMP +TPS termasuk ke dalam tingkatan amat sangat tinggi, sedangkan kemampuan berpikir kritis yang diajarkan dengan model pembelajaran TPS termasuk dalam tingkatan sedang.

\section{PEMBAHASAN}

\section{Pengaruh model pembelajaran terhadap kemampuan berpikir kritis}

Hasil analisis data menunjukan bahwa model pembelajaran TPS + PBMP berpengaruh terhadap kemampuan berpikir kritis siswa dengan nilai probabilitas $0,000<0,05$, jadi terdapat perbedaan yang tidak terlalu signifikan antara siswa yang mendapat pembelajaran model PBMP + TPS dengan siswa yang mendapatkan pembelajaran dengan model pembelajaran TPS maupun PBMP. Berdasarkan hasil uji LSD juga dapat diketahui bahwa model pembelajaran PBMP+TPS dapat meningkatkan kemampuan berpikir kritis siswa yang paling tinggi dan berbeda nyata dengan model pembelajaran TPS dan PBMP.

Model TPS+PBMP dapat meningkatkan berpikir kritis disebabkan pembelajaran ini berupa jalinan pertanyaan yang dapat memicu siswa untuk berpikir dan menjawab pertanyaan serta memecahkan masalah yang ada di dalam lembar PBMP. PBMP merupakan pembelajaran kontruktivis, sehingga dapat membantu memberdayakan kemampuan berpikir kritis siswa. Pembelajaran 
kontruktivis yang menuntut siswa membangun pengetahuannya sendiri sebenarnya adalah pembelajaran berbasis kemampuan berpikir. Pada lembar PBMP memfasilitasi siswa untuk berpartisipasi aktif mengkontruksi pengetahuannya, sehingga dalam proses tersebut siswa dapat mereview pengetahuan awal yang telah dimiliki, menerapkannya dalam situasi yang baru terutama pada kehidupan seharihari siswa, kemudian akan mengitegrasikan pengetahuan tersebut ke struktur pengetahuan.

Hasil penelitian ini sejalan dengan penelitian yang telah dilakukan oleh Hartati (2010), model pembelajaran Think Pair Share yang dipadu dengan pola pemberdayaan berpikir melalui pertanyaan dapat meningkatkan keterampilan metakognitif, kemampuan berpikir kritis dan hasil belajar kognitif. Hasil penelitian Suyanik (2010), membuktikan bahwa pemberdayaan berpikir melalui pertanyaan dengan model pembelajaran Think Pair Share berpengaruh secara signifikan terhadap hasil belajar kognitif. Hasil penelitian Imkari (2012), pengaruh model TPS dan PBMP terhadap kemampuan berpikir kritis,hasil belajar kognitif, dan retensi mahasiswa. Hasil penelitian Haerullah (2012), pola Pemberdayaan Berpikir Melalui Pertanyaan dan Thing Pair Share dapat meningkatkan metakognisi, berpikir kritis dan sikap sosial siswa.

Pembelajaran model TPS+ PBMP melatih siswa untuk berpikir kritis dalam memecahkan masalah dan bekerja dalam kelompok untuk merumuskan masalah, memberikan dan menganalisis argumen, melakukan observasi, menyusun hipotesis, melakukan deduksi dan induksi, mengevaluasi dan mengambil keputusan serta melaksanakan tindakan.

Menurut Zubaidah (2001) yang dikutip oleh Haerullah (2012), bahwa model pembelajaran TPS dan TPS+ PBMP dapat melatih kemampuan berpikir siswa dalam hal pengetahuan, pemahaman, penerapan, analisis, sintesis, dan evaluasi melalui pembelajaran dengan Lembar PBMP diharapkan dapat dikembangkan kemampuan berpikir kritis, yang merupakan salah satu ciri berkembangnya penalaran formal. Seperti yang dikemukakan oleh Crown (1996) dalam Imkari (2012), bahwa kemampuan berpikir kritis dapat dikembangkan melalui berbagai aktivitas, diantaranya melalui pertanyaan. Pertanyaan yang dikemas dengan baik dapat melatih siswa pada kemampuan perkembangan berpikir kritis. Guna merealisasikan pendapat tersebut, Corebima mengembangkan model pembelajaran yang terbukti dapat meningkatkan kemampuan berpikir kritis siswa, selanjutnya dikenal dengan PBMP (Pemberdayaan Berpikir Melalui Pertanyaan) (Corebima, 2005), dengan adanya pembelajaran yang berpola PBMP dan model TPS dapat mengembangkan kemampuan berpikir kritis dan hasil belajar kognitif. 
Mengacu pada taksonomi kognitif bloom, (Lawrence dalam Aryana 2004) menggolongkan keterampilan berfikir menjadi dua yaitu 1) berfikir tingkat rendah yang meliputi pengetahuan, pemahaman, dan aplikasi, dan 2) berfikir tingkat tinggi yang terdiri dari analisis, sintesis dan evaluasi. Jadi berpikir kritis merupakan proses kognitif dalam tingkatan analisis, aplikasi, evaluasi, dan sintesis sehingga apabila seorang siswa mampu memahami suatu materi dengan baik dan mampu memecahkan masalah yang dihadapi (salah satu indikator berpikir kritis) sehingga hasil belajar kognitifnya tinggi.

Penggabungan antara pola PBMP dan TPS mampu menjadi salah satu cara efektif untuk dapat meningkatkan kemampuan berfikir siswa. Kemampuan berpikir kritis merupakan proses kognitif dalam tingkatan analisis, aplikasi, evaluasi dan sintesis sehingga apabila seorang siswa memiliki kemampuan berfikir kritis dan mampu untuk memecahkan masalah yang dihadapi sehingga hasil belajar kognitifnya tinggi. Berdasarkan uraian di atas diketahui bahwa penggabungan antara pola PBMP dan TPS mampu menjadi salah satu cara efektif untuk dapat meningkatkan kemampuan berfikir siswa.(Zubaidah, 2005 ; Imkari, 2012; Haerullah, 2012 ).

Selanjutnya menurut Haerullah (2012), bahwa penerapan strategi PBMP dipadukan TPS dapat meningkatkan kemampuan berpikir siswa karena strategi ini memberikan kesempatan siswa untuk memikirkan jawaban dan mengevaluasi jawaban bersama pada tahap think dan share. Sedangkan pada tahap pair, siswa dilatih untuk berkomunikasi mencari pemecahan masalah yang terbaik bersama dengan temannya. Selain itu bahwa pada tahap think, share maupun tahap pair, siswa diberi kesempatan pula untuk mengatur proses berpikirnya dan atas dasar hasil berpikirnya kemudian dapat memcahkan masalah secara bersama-sama dengan siswa lain. Menurut Corebima (2005) pengaturan proses berpikir inilah yang disebut dengan kemampuan berpikir kritis.

\section{SIMPULAN}

Berdasarkan analisis data dan pembahasan, maka dapat disimpulkan bahwa perpaduan model pembelajaran TPS + PBMP dapat meningkatkan kemampuan berpikir kritis siswa di SMA Negeri 10 Kota Ternate, dan tidak terlalu berbeda nyata dengan model TPS dan PBMP yang juga dapat meningkatkan kemampuan berpikir kritis siswa. 


\section{DAFTAR PUSTAKA}

Anderson, L.W. and Krathwohl, D.R. 2001. A Taoconomy for Learning, Teaching, and Assesing: A Revision of Bloom's Taoconomy of Educational Objectives. New York: Addison Wesley Longman.

Ardana. W. 2005. Kostruktivisme dan Penerapan dalam Pembelajaran. Makalah Disejikan pada Seminar dan Lokakarya Pembelajaran Berbasis Kostruktivitas, Jurusan Kimia FMIPA Universitas Negeri Malang. Malang 22 Juni 2005.

Arends, R.I. 2004. Learning To Teach. Sixth Edition. New York: Mcgraw Hill.

Arikunto, S. 2001. Dasar-Dasar Evaluasi Pendidikan. Jakarta: Bumi Aksara.

Azwar, S.2007. Reliabilitas Dan Validitas. Yogyakarta: Pustaka Pelajar.

Corebima, A.D. 2005a. Pemberdayaan Berpikir Siswa Pada Pembelajaran Biologi: Satu Pengalakan Penelitian Payung Dijurusan Biologi UM. Makalah Disajikan Dalam Seminar Nasional Biologi Dan Pembelajarannya. Malang, 3 Desember 2005.

Corebima, A.D. 2005b. Pengembangan Model Pembelajaran IPA Biologi SMP Konstruktuvistik Kontekstual Berorientasi Life Skill dengan Pola PBMP (Pemberdayaan Berpikir Melalui Pertanyaan ) Dikota dan Kabupaten Malang. Laporan Penelitian Akhir Tahun RUKK V Periode 1 Febuari-30 November 2005. Malang: Universitas Negeri Malang.

Depdiknas. 2005. Standar Nasional Pandidikan. Peraturan Pemerintah Republik Indonesia Nomor 19 Tahun 2005. Jakarta :Depdiknas.

Depdiknas. 2007. Permendiknas No..41 Tahun 2007, Standar Proses. Jakarta: Depdiknas.

Haerullah, A. 2012. Pengembangan Perangkat Pembelajaran IPA Berpola Pemberdayaan Berpikir Melalui Pertanyaan (PBMP) dan Thing Pair Share (TPS) pada sekolah multietnis dan pengaruh penerapannya terhadap Metakognisi,Berpikir Kritis dan Sikap Sosial Siswa. Universitas Negeri Malang.

Haerullah, A. 2017. Ketrampilan Dasar Mengajar Guru IPA.Lintas Nalar. Yogyakarta.

Haerullah, A dan Hasan, S. 2017. Model dan Pendekatan Pembelajaran Inovatif. Edisi 1,Lintas Nalar.Yogyakarta.

Ibrahim, M. Dan Nur, M. 2000. Pengajaran Berdasar Masalah. Surabaya: UNESA-University Press.

Imkari,S. 2012. Pengaruh Model Pembelajaran TPS dan PBMP Terhadap kemampuan Berpikir Kritis,Hasil Belajar Kognitif dan Retensi Mahasisiwa. Universitas Negeri Malang.

Isjoni. 2007. Paradikma Pembelajaran Bermakna. Bandung: Falah Production.

Jurnal Pendidikan. 2013. Volume 11 Nomor 2, Fakultas Keguruan dan Ilmu Pendidikan. Unkhair-Ternate. 
Muhfahroyin. 2007b. KTSP Sebagai Kurikulum Berbasis Kompetensi. Menuntut Guru Kreatif dan Inovatif. Prosiding, Seminar Nasional Peningkatan Mutu dan Profesionalisme Pendidikan dan Tenaga Kependidikan, Universitas Muhammadiya Metro, 16 Mei 2007.

Muhfahroin. 2018b. Implementasi pembelajaran konstruktivistik. Makalah disajikan dalam Seminar Nasional Hasil Penelitian Tindakan Kelas Mata Pelajaran Biologi Bagi Guru SMA, MGMP Biologi SMA Kota Malang, Malang, 15 Nopember 2008.

Nasir, M. 2005. Metode penelitian. Bogor. Ghalia Indonesia.

Nasution, S. 1998. Berbagai pendekatan dalam proses belajar mengajar. Jakarta: Bina Aksara.

Rustini, I, 2005. Keterampilan Berpikir Kritis Siswa Melalui Pembelajaran Kooperatif Teknik Think-Square dalam Kegiatan Praktikum Materi Pencemaran Air (Studi Kasus SMA 2 Bandung Kelas X), (Online), (http//digilib.upi. edu/pascal available/ etd- 0202106- 091451/, diakses 6 nopember 2007.

Safitri, D.A.A. 2008. Penerapan Model Pembelajaran Kooperatif Model TPS Untuk Meningkatkan Kemampuan Berpikir dan Prestasi Belajar Siswa Kelas XI IPS II SMAN 1 Boyolangu Tulangagung. Skiripsi tidak diterbitkan. Malang: Universitas Negeri Malang.

Slavin, R.E. 2006. Psikologi Pendidikan Teori dan Praktek. Terjemahan oleh Marianto Samosir. 2008. Jakarta P.T. Indeks.

Surapranata, S. 2004. Analisis Validitas, Realiabilitas, dan Interpretasi Hasil Tes Implementasi Kurikulum: Bandung: Remaja Rosda Karya.

Zamroni. 2003. Paradigma Pendidikan Masa Depan. Proyek Perluasan Dan Peningkatan Mutu SMU. Jakarta: Depdikmas.

Zubaidah, S. 2005. Assesmen dalam Penerapan PBMP (Pemberdayaan Berpikir melalui Pertanyaan) melalui Pembelajaran Kooperatif Model TPS (Think Pair Share). Makalah disampaikan dalam Workshop PTK di Universitas Negeri Malang, Malang, 28 Juni 2005. 